Scientia Agricola

http://dx.doi.org/10.1590/0103-9016-2015-0170

\title{
Residual recovery and yield performance of nitrogen fertilizer applied at sugarcane
}

\section{planting}

\author{
Henrique Coutinho Junqueira Franco ${ }^{1 *}$, Rafael Otto ${ }^{2}$, André Cesar Vitti ${ }^{3}$, Carlos Eduardo Faroni², Emídio Cantídio de Almeida \\ Oliveira², Caio Fortes ${ }^{4}$, Danilo Alves Ferreira ${ }^{1}$, Oriel Tiago Köllnn ${ }^{1}$, Alan Leslie Garside ${ }^{5}$, Paulo Cesar Ocheuze Trivelin ${ }^{4}$
}

\author{
'Brazilian Bioethanol Science and Tecnology Laboratory, \\ R. Giuseppe Máximo Scalfaro, 10.000 - 13083-970 - \\ Campinas, SP - Brazil. \\ 2University of São Paulo/ESALQ, Av. Pádua Dias, 11 - \\ 13418-900 - Piracicaba, SP - Brazil. \\ 3São Paulo Agency of Technology for Agribusiness, Rod. SP \\ 127, km 30 - 13400-970 - Piracicaba, SP - Brazil. \\ 4University of São Paulo/CENA, Av. Centenário, 303 - \\ 13400-970 - Piracicaba, SP - Brazil. \\ 5 James Cook University, Townsville, QLD 4811 - Australia. \\ *Corresponding author <henrique.franco@bioetanol.org.br> \\ Edited by: Richard L. Mulvaney
}

Received April 27, 2015

Accepted July 06, 2015

\begin{abstract}
The low effectiveness of nitrogen fertilizer $(N)$ is a substantial concern that threatens global sugarcane production. The aim of the research reported in this paper was to assess the residual effect of $\mathrm{N}$-fertilizer applied at sugarcane planting over four crop seasons in relation to sugarcane crop yield. Toward this end three field experiments were established in the state of São Paulo, Brazil, during February of 2005 and July of 2009, in a randomized block design with four treatments: $0,40,80$ and $120 \mathrm{~kg} \mathrm{ha}^{-1}$ of $\mathrm{N}$ applied as urea during sugarcane planting. Within each plot, a microplot was established to which ${ }^{15} \mathrm{~N}$-labeled urea was applied. The application of $\mathrm{N}$ at planting increased plant cane yield in two of the three sites and sucrose content at the other, whereas the only residual effect was higher sucrose content in one of the following ratoons. The combined effect was an increase in sugar yield for three of the $11 \mathrm{crop}$ seasons evaluated. Over the crop cycle of a plant cane and three ratoon crops, only $35 \%$ of the applied $\mathrm{N}$ was recovered, split $75,13,7$ and $5 \%$ in the plant cane, first, second and third ratoons, respectively. These findings document the low efficiency of $\mathrm{N}$ recovery by sugarcane, which increases the risk that excessive $\mathrm{N}$ fertilization will reduce profitability and have an adverse effect on the environment.

Keywords: Saccharum, urea, nitrogen fertilization, isotopic technique
\end{abstract}

\section{Introduction}

In Brazil, sugarcane research has concentrated on assessing sugarcane as an annual crop, with few studies assessing the crop over a whole crop cycle (plant cane and ratoons). Many sugarcane technicians know that if $\mathrm{N}$-fertilizer is not applied, productivity in the following ratoon will be adversely affected, and decrease the number of crops in a cycle. In a study over four crop seasons, Orlando Filho et al. (1999) verified this effect and affirmed that $\mathrm{N}$ fertilization of plant cane has a positive impact on the growth and vigor of the ratoon, and increases the yield of stalks in sugarcane ratoons. Vitti et al. (2007) also observed substantial residual effect in the fourth ratoon yield of $\mathrm{N}$ fertilization applied in the third ratoon.

Thus, it is appropriate to question $\mathrm{N}$ fertilizer strategies for sugarcane, in particular those applied to the first crop (plant cane), in relation to root growth, storage of nutrients in the belowground part of the crop, and whether this stored $\mathrm{N}$ is used by the following ratoon crop. Previous works have shown that $\mathrm{N}$ fertilization increases $\mathrm{N}$ storage in sugarcane root systems (Bologna-Campbell et al., 2013; Vitti et al., 2007); however, the importance of this increased storage of $\mathrm{N}$ in the root system depends on whether it is be utilized by subsequent ratoons. Can the $\mathrm{N}$-fertilizer applied at sugarcane planting be used by the ratoon? This issue has seldom been investigated in Brazil or elsewhere, because it requires the use of ${ }^{15} \mathrm{~N}$-labeled fertilizer as an isotopic tracer. Our aim was to assess the residual effect of ${ }^{15} \mathrm{~N}$-fertilizer applied at sugarcane planting through the evaluation of ${ }^{15} \mathrm{~N}$ recovery by sugarcane ratoons in relation to sugarcane crop yield.

\section{Materials and Methods}

\section{Description of experiments}

Three field trials were carried out in the southeast of Brazil, in the state of Sao Paulo, the largest sugarcane producing region in Brazil. Details regarding the experimental sites are shown in Table 1. All of the sites have a history of over 30 years under sugarcane cultivation.

The field experiments were established in February, 2005 at Pirassununga (São Luiz Sugar Mill - SL) (Typic Hapludox), in April, 2005 at Jaboticabal (Santa Adélia Sugar Mill - SA) (Typic Kandiudox) and in March, 2005 at Pradópolis (São Martinho Sugar Mill - SM) (Rhodic Eutrudox) (Table 1). Details of soil tillage practices, fertilizer applications, weed control and other management practices adopted in the experimental fields can be found in Franco et al. $(2010,2011)$ for the SL and SA sites, and in Fortes et al. (2012) for the SM site. For all three experimental sites, the predominant regional climate is classified as Koppen Aw Tropical Savanna.

For planting sugarcane, two stalk pieces (seeds) per meter were used, providing a distribution of 17-20 buds $\mathrm{m}^{-1}$ of furrow. The stalks deposited in the furrow were cut into stalk pieces with 2-3 buds and covered with soil (mechanized operation). The sugarcane variety used was SP81 3250 since it is highly adaptable, very productive and one of the most common varieties planted in the centre-south region of Brazil. In all of the plots at the bottom of the furrow, $120 \mathrm{~kg} \mathrm{ha}^{-1}$ of $\mathrm{K}_{2} \mathrm{O}$ and $120 \mathrm{~kg} \mathrm{ha}^{-1}$ of $\mathrm{P}_{2} \mathrm{O}_{5}$ were applied in the form of potassium chloride and triple superphosphate, respectively. 
Table 1 - Details of experimental sites.

\begin{tabular}{|c|c|c|c|}
\hline & \multicolumn{3}{|c|}{ Experimental sites } \\
\hline & SL & SA & SM \\
\hline Location & Pirassununga, SP 215' S; 47 11' W & Jaboticabal, SP $21^{\circ} 20^{\prime}$ S; 48¹9’W & 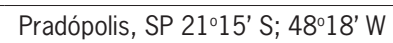 \\
\hline Altitude (m) & 650 & 600 & 580 \\
\hline Reference & Franco et al. $(2010,2011)$ & Franco et al. $(2010,2011)$ & Fortes et al. (2012) \\
\hline Variety & SP81 3250 & SP81 3250 & SP81 3250 \\
\hline Replicates & 16 & 16 & 16 \\
\hline Plot size $\left(m^{2}\right)$ & 270 & 270 & 270 \\
\hline Space between rows (m) & 1.50 & 1.50 & 1.50 \\
\hline Soil tillage & $\begin{array}{c}\text { Herbicide application, chisel plowing } \\
(0.40 \mathrm{~m}) \text {, grading }(0.25 \mathrm{~m}) \text { and furrowing }(0.35 \mathrm{~m})\end{array}$ & $\begin{array}{l}\text { Deep plowing }(0.40 \mathrm{~m}) \text {, grading (twice, } \\
0.25 \mathrm{~m}) \text { and furrowing }(0.35 \mathrm{~m})\end{array}$ & $\begin{array}{l}\text { Herbicide application, chisel plowing } \\
(0.40 \mathrm{~m}) \text { and furrowing }(0.35 \mathrm{~m})\end{array}$ \\
\hline $\begin{array}{l}\text { Soil Classification } \\
\text { (Soil Survey Staff, 2010) }\end{array}$ & Typic Hapludox & Typic Kandiudox & Rhodic Eutrudox \\
\hline Soil Texture & Sandy Clay Loam & Sandy Clay Loam & Clay \\
\hline \multicolumn{4}{|l|}{ Month/Year } \\
\hline Planted & Feb/2005 & Apr/2005 & Mar/2005 \\
\hline First harvest & Jun/2006 & Jul/2006 & Aug/2006 \\
\hline Second harvest & Jun/2007 & $\mathrm{Jul} / 2007$ & Aug/2007 \\
\hline Third harvest & $\mathrm{Jul} / 2008$ & $\mathrm{Jul} / 2008$ & $\mathrm{Jul} / 2008$ \\
\hline Fourth harvest & $\mathrm{Jul} / 2009$ & $\mathrm{Jul} / 2009$ & $\mathrm{Jul} / 2009$ \\
\hline Meterological data & \multicolumn{3}{|c|}{ Average of four years $(2006,2007,2008$ and 2009) } \\
\hline Rainfall & 1476 & 1382 & 1580 \\
\hline ETc & 1693 & 1573 & 1380 \\
\hline ETr & 1359 & 1080 & 1002 \\
\hline
\end{tabular}

SL - São Luiz Sugar Mill experiment located in Pirassununga; SA - Santa Adélia Sugar Mill experiment located in Jaboticabal; SM São Martinho Sugar Mill experiment located in Pradópolis; ETc = crop evapotranspiration; ETr = real evapotranspiration.

\section{Treatments}

Fertilizer treatments at planting consisted of four $\mathrm{N}$ amounts $\left(0,40,80\right.$ and $120 \mathrm{~kg} \mathrm{ha}^{-1}$ of $\mathrm{N}$ as urea) applied at the bottom of the planting furrow. These amounts were chosen based on Technical Bulletin 100 (Spironello et al., 1997), which recommends the application of up to $90 \mathrm{~kg} \mathrm{ha}^{-1}$ of $\mathrm{N}$ at planting. The treatments were arranged in a randomized block design with four replicates. The experimental plots were composed of 48 rows, $15 \mathrm{~m}$ in length with a space of $1.5 \mathrm{~m}$ between rows. Inside each treatment plot of 40 , 80 and $120 \mathrm{~kg} \mathrm{ha}^{-1}$ of $\mathrm{N}$, a microplot $(2 \mathrm{~m}$ long and $1.5 \mathrm{~m}$ wide, totalling $3 \mathrm{~m}^{2}$ ) received urea labeled with 4.67 atom $\%$ excess ${ }^{15} \mathrm{~N}$. In the SM experiment, only the treatment with $80 \mathrm{~kg} \mathrm{ha}^{-1} \mathrm{~N}$ was evaluated in terms of ${ }^{15} \mathrm{~N}$-fertilizer recovery.

After plant cane harvest, no N-fertilizer was applied to three subsequent ratoons. Potassium chloride (at a rate of $150 \mathrm{~kg} \mathrm{ha}^{-1} \mathrm{~K}_{2} \mathrm{O}$ ) was applied after every harvest, as well as triple superphosphate (at a rate of $60 \mathrm{~kg} \mathrm{ha}^{-1} \mathrm{P}_{2} \mathrm{O}_{5}$ ) in the SL experiment after the second harvest. Fertilizers were applied over the crop residue (trash) approximately $20 \mathrm{~cm}$ from the sugarcane row. The microplots that received ${ }^{15} \mathrm{~N}$-fertilizer at planting were kept to evaluate the residual effect of $\mathrm{N}$ applied at planting.

\section{Sampling and analyses}

In the plant cane crop, the sugarcane harvest was performed 16, 15 and 17 months after planting in SL,
SA and SM sites, respectively. After the first harvest, the experimental sites were harvested successively after 12-months until the fourth harvest (Table 1). However, owing to an accidental fire, it was not possible to evaluate the 2008 crop at the SL site.

For yield measurements, four sugarcane rows of each plot were mechanically harvested and the stalks deposited in a truck coupled to a scale. The stalk mass registered was used to calculate stalk yield. Prior to harvesting, ten stalks per plot were collected and analyzed for sugar content. The sugar yield was calculated based on stalk yield and sucrose content, and was expressed in $\mathrm{Mg} \mathrm{ha}^{-1}$.

The isotopic tracer technique allows for estimation of the percentage of $\mathrm{N}$ in the plant that is derived from fertilizer (NDFF) and the fertilizer use efficiency. The measurement of ${ }^{15} \mathrm{~N}$-fertilizer recovery by aboveground and belowground sugarcane was always taken at the end of each crop phase, one week before the mechanical harvest of sugarcane.

The evaluation was carried out within $1.0 \mathrm{~m}$ of the center of the microplot row and the two adjacent rows, keeping the samples separate according to the methods described by Trivelin et al. (1994). Whole plants from the $1.0 \mathrm{~m}$ sections were harvested to obtain separate samples of stalks, dry leaves and tops. The fresh mass of plant parts was evaluated directly in the field with a weighing scale, followed by mulching with a mechanical forage chopper. Homogenized sub-samples were prepared (Trivelin et al., 1994), dried at $65{ }^{\circ} \mathrm{C}$ to constant weight and finely ground with a Wiley mill to enable 
determination of total $\mathrm{N}$ and ${ }^{15} \mathrm{~N}$ using a Hydra 20-20 mass spectrometer coupled to an automatic $\mathrm{N}$ analyzer ANCA-SGL (Barrie and Prosser, 1996).

For belowground measurements, root samples were collected in the same area that had been previously sampled for aboveground measurements, using a root sampling probe $(5.5-\mathrm{cm}$ internal diameter) that was inserted to a depth of $0.6 \mathrm{~m}$ at several points in relation to the row (Otto et al., 2009). The resulting cores were segmented in $0.2 \mathrm{~m}$ increments, as $50 \%$ of sugarcane root biomass is typically found in the upper $0.2 \mathrm{~m}$ soil layer and $85 \%$ in the upper $0.6 \mathrm{~m}$ layer (Blackburn, 1984). The decision to use the probe method was based on the need to minimize disturbance in the plot, so that measurements could be repeated over multiple years in the same plot. In previous work by Otto et al. (2009), the probe method enabled higher throughput than the monolith method, while giving similar results. Root samples were segregated by sieving ( $2 \mathrm{~mm}$ mesh), dried in an oven $\left(65^{\circ} \mathrm{C}\right)$ and then ground to $<0.595 \mathrm{~mm}$ using a Wiley mill. Analyses for total $\mathrm{N}$ and ${ }^{15} \mathrm{~N}$ were performed by continuous flow mass spectrometry.

Measurements of ${ }^{15} \mathrm{~N}$-fertilizer recovery were repeated every year before the sugarcane harvest, using the previously presented methodology. Nitrogen recovery from fertilizer and crop residues was calculated as described in Trivelin et al. (1994).

\section{Meteorological data}

Throughout the entire experimental period, meteorological data (rainfall, solar radiation, wind speed, relative humidity and temperature) were measured by means of automatic meteorological stations installed near the three experimental areas. Four-year average rainfall and evapotranspiration (ET) data are summarized in Table 1.

\section{Data analysis}

For stalk yield, sucrose content and sugar yield, total $\mathrm{N}\left(\mathrm{kg} \mathrm{ha}^{-1}\right)$ and NDFF (\% and $\left.\mathrm{kg} \mathrm{ha}^{-1}\right)$ data for individual site-years were analyzed by means of analysis of variance (ANOVA), considering differences to be significant when the probability was lower than $10 \%(p<$ $0.10)$. When the $\mathrm{F}$ test was significant, the Tukey test ( $p$ $<0.05$ ) was performed to compare the means.

\section{Results}

There was a positive effect of $\mathrm{N}$ applied at planting on the stalk yield of plant cane in the SM and SL experiments, and also a positive effect on the sucrose content of plant cane at the SA site (Table 2). Reduced tillage may have contributed to the $\mathrm{N}$ response observed in the SM experiment, in comparison to conventional tillage that was in use at the remaining sites (Table 1).

None of the three sites showed any residual effect of $\mathrm{N}$ applied at planting on the yield of the following sugarcane crop cycles, nor there was an effect
Table 2 - Sugarcane stalk yield, sucrose content $\left(\mathrm{g} \mathrm{kg}^{-1}\right)$ and sugar yield $\left(\mathrm{Mg} \mathrm{ha}^{-1}\right)$ in four crop seasons as related to $\mathrm{N}$ rates applied at planting, for three experimental sites.

\begin{tabular}{|c|c|c|c|c|c|}
\hline \multirow{2}{*}{$\begin{array}{l}\text { N rate } \\
\mathrm{kg} \mathrm{ha}^{-1}\end{array}$} & \multicolumn{4}{|c|}{ Crop } & \multirow[b]{2}{*}{ Total } \\
\hline & Plant cane & $1^{\text {st }}$ ratoon & $2^{\text {nd }}$ ratoon & $3^{\text {rd }}$ ratoon & \\
\hline & \multicolumn{5}{|c|}{ - Stalk yield $\left(\mathrm{Mg} \mathrm{ha}^{-1}\right)$} \\
\hline & \multicolumn{5}{|c|}{ SA } \\
\hline 0 & 144.83 & 117.74 & 107.85 & 109.10 & 479.52 \\
\hline 40 & 143.75 & 118.23 & 105.31 & 108.02 & 475.31 \\
\hline 80 & 146.84 & 121.91 & 106.60 & 109.90 & 485.25 \\
\hline 120 & 146.11 & 119.72 & 104.10 & 109.48 & 479.41 \\
\hline \multirow[t]{2}{*}{$p<n$} & 0.8582 & 0.4977 & 0.4756 & 0.9081 & 0.8106 \\
\hline & \multicolumn{5}{|c|}{ SL } \\
\hline 0 & 134.16 & 80.10 & \# & 99.72 & 313.98 \\
\hline 40 & 141.63 & 85.90 & - & 101.63 & 329.17 \\
\hline 80 & 138.61 & 84.24 & - & 102.60 & 325.45 \\
\hline 120 & 141.32 & 81.98 & - & 100.76 & 324.06 \\
\hline \multirow[t]{2}{*}{$p<n$} & 0.0623 & 0.2612 & - & 0.7457 & 0.4431 \\
\hline & \multicolumn{5}{|c|}{ SM } \\
\hline 0 & 141.26 & 81.56 & 63.81 & 88.61 & 375.25 \\
\hline 40 & 152.64 & 76.52 & 60.45 & 88.40 & 378.02 \\
\hline 80 & 155.69 & 78.10 & 58.40 & 89.79 & 381.98 \\
\hline 120 & 159.12 & 81.66 & 63.99 & 90.45 & 395.22 \\
\hline \multirow[t]{3}{*}{$p<n$} & 0.0005 & 0.2547 & 0.1204 & 0.8512 & 0.2276 \\
\hline & \multicolumn{5}{|c|}{ - Sucrose content $\left(\mathrm{g} \mathrm{kg}^{-1}\right)$} \\
\hline & \multicolumn{5}{|c|}{ SA } \\
\hline 0 & 156.2 & 147.0 & 150.8 & 136.3 & 147.6 \\
\hline 40 & 169.5 & 148.7 & 153.9 & 137.9 & 152.5 \\
\hline 80 & 168.3 & 151.4 & 155.5 & 145.5 & 155.2 \\
\hline 120 & 157.6 & 147.9 & 153.0 & 143.4 & 150.5 \\
\hline \multirow[t]{2}{*}{$p<n$} & 0.0251 & 0.1402 & 0.2002 & 0.0022 & 0.2474 \\
\hline & \multicolumn{5}{|c|}{ SL } \\
\hline 0 & 145.4 & 138.8 & \# & 140.3 & 141.5 \\
\hline 40 & 147.3 & 135.9 & - & 141.9 & 141.7 \\
\hline 80 & 146.5 & 134.8 & - & 141.1 & 140.8 \\
\hline 120 & 138.4 & 135.0 & - & 140.9 & 138.1 \\
\hline \multirow[t]{2}{*}{$p<n$} & 0.3068 & 0.1633 & - & 0.8445 & 0.7073 \\
\hline & \multicolumn{5}{|c|}{ SM } \\
\hline 0 & 166.6 & 161.2 & 169.2 & 169.7 & 166.7 \\
\hline 40 & 175.4 & 161.2 & 166.1 & 167.7 & 167.6 \\
\hline 80 & 166.6 & 158.7 & 168.2 & 165.7 & 164.8 \\
\hline 120 & 172.2 & 161.9 & 168.0 & 168.1 & 167.6 \\
\hline$p<n$ & 0.2625 & 0.3297 & 0.5018 & 0.2571 & 0.8261 \\
\hline & & - Sugar yi & ld $\left(\mathrm{Mg} \mathrm{ha}^{-1}\right.$ & & \\
\hline & & & SA & & \\
\hline 0 & 22.62 & 17.28 & 16.26 & 14.89 & 71.05 \\
\hline 40 & 24.39 & 17.57 & 16.19 & 14.91 & 73.06 \\
\hline 80 & 24.72 & 18.46 & 16.56 & 15.99 & 75.73 \\
\hline 120 & 23.01 & 17.71 & 15.96 & 15.73 & 72.41 \\
\hline$p<n$ & 0.1024 & 0.0847 & 0.6912 & 0.0998 & 0.3535 \\
\hline & & & SL & & \\
\hline 0 & 19.48 & 11.11 & \# & 13.99 & 44.59 \\
\hline 40 & 20.86 & 11.68 & - & 14.41 & 46.95 \\
\hline 80 & 20.34 & 11.37 & - & 14.47 & 46.17 \\
\hline 120 & 19.50 & 11.09 & - & 14.19 & 44.78 \\
\hline$p<n$ & 0.4208 & 0.4674 & - & 0.7448 & 0.6924 \\
\hline & & & SM & & \\
\hline 0 & 23.54 & 13.14 & 10.80 & 15.04 & 62.51 \\
\hline 40 & 26.78 & 12.33 & 10.04 & 14.78 & 63.93 \\
\hline 80 & 25.91 & 12.38 & 9.82 & 14.86 & 62.96 \\
\hline 120 & 27.42 & 13.22 & 10.76 & 15.22 & 66.61 \\
\hline$p<n$ & 0.0023 & 0.1053 & 0.1777 & 0.8039 & 0.3482 \\
\hline
\end{tabular}

SL - São Luiz Sugar Mill experiment located in Pirassununga; SA - Santa Adélia Sugar Mill experiment located in Jaboticabal; SM - São Martinho Sugar Mill experiment located in Pradópolis; $p<\mathrm{n}$ indicates the probability by ANOVA analysis; "Data not obtained. 
on the accumulated yield for the four harvests. The only residual effect was an increase in sucrose content for the third ratoon crop at the SA experiment (Table 2), an uncommon trend when compared to published results.

Due to an increase in stalk yield or in sucrose content (Table 2), the combined effect on sugar yield was an increase in 3 of the 11 site-years evaluated $p$ $<0.10)$. Most of the positive results were found in the SA experiment, followed by SM. There was no effect of $\mathrm{N}$ applied at planting for any of the years evaluated in the SL experiment, or for any ratoon harvest at the SM site.

With regard to crop $\mathrm{N}$ recovery, after four years of evaluation it was found that $75 \%$ of all fertilizer ${ }^{15} \mathrm{~N}$ uptake in the SA experiment was by the plant cane, whilst residual recoveries of ${ }^{15} \mathrm{~N}$ applied at planting were $14 \%, 5 \%$ and $6 \%$, respectively, for the first, second and third ratoon (Table 3). The results were very similar for the SM experiment, with $73 \%$ of fertilizer ${ }^{15} \mathrm{~N}$ uptake being by plant cane, $11 \%$ by the first ratoon, $8 \%$ by the second ratoon and $8 \%$ by the third ratoon (Table 4). As already mentioned for the SL experiment (Table 5), it was only possible to assess ${ }^{15} \mathrm{~N}$ recovery in the plant cane and first ratoon, because of an accidental fire during the second ratoon that led to the loss of biomass material from the microplots. However, the results of two crops (plant and first ratoon) in this experiment showed the same trend observed in the SA and SM experiments, where the majority of fertilizer ${ }^{15} \mathrm{~N}$ uptake was by plant cane $(86 \%)$. Taken together, the data in Tables 3-5 show that $\mathrm{N}$ fertilize applied at planting is quite limited in availability to the subsequent ratoons, especially in relation to total $\mathrm{N}$ uptake for sugarcane growth that can vary between 100 and $200 \mathrm{~kg} \mathrm{ha}^{-1}$ (Franco et al., 2011).

After four growing seasons, crop recovery of fertilizer ${ }^{15} \mathrm{~N}$ in the SA experiment totaled about 40, 35 and $30 \%$ for $\mathrm{N}$ amounts of 40,80 and $120 \mathrm{~kg} \mathrm{ha}^{-1}$, respectively (Table 3). By comparison, total ${ }^{15} \mathrm{~N}$ recovery in the SM experiment was $45 \%$ with $80 \mathrm{~kg} \mathrm{~N}^{-1}$ (Table $4)$, while for two crops at the SL site, recoveries totaled 35,40 and $27 \%$, respectively, for 40,80 and $120 \mathrm{~kg}$ $\mathrm{N}$ ha ${ }^{-1}$ (Table 5). Based on these data it is evident that 60 to $70 \%$ of the fertilizer $\mathrm{N}$ applied at planting had another fate.

\section{Discussion}

The present findings provide little evidence of a residual benefit from $\mathrm{N}$ applied to sugarcane at planting, and are consistent with a previous study by Vieira et al. (2010) but not with another by Vitti et al. (2007). Such disparities no doubt reflect differences due to soil

Table 3 - Recovery of ${ }^{15} \mathrm{~N}$-fertilizer ( $k g$ ha ${ }^{-1}$ and \%) applied at sugarcane planting, as evaluated in four crop seasons. Santa Adelia Experiment - SA.

\begin{tabular}{|c|c|c|c|c|c|c|c|c|c|c|c|c|}
\hline \multirow{2}{*}{$\begin{array}{l}\text { N Rates } \\
\mathrm{kg} \mathrm{ha}^{-1}\end{array}$} & \multicolumn{2}{|c|}{ Stalks } & \multicolumn{2}{|c|}{ Dry Leaves } & \multicolumn{2}{|c|}{ Tops } & \multicolumn{2}{|c|}{ Above ground } & \multicolumn{2}{|c|}{ Roots } & \multicolumn{2}{|c|}{ Whole Plant } \\
\hline & $\mathrm{kg} \mathrm{ha}^{-1}$ & $\%$ & $\mathrm{~kg} \mathrm{ha}^{-1}$ & $\%$ & $\mathrm{~kg} \mathrm{ha}^{-1}$ & $\%$ & $\mathrm{~kg} \mathrm{ha}^{-1}$ & $\%$ & $\mathrm{~kg} \mathrm{ha}^{-1}$ & $\%$ & $\mathrm{~kg} \mathrm{ha}^{-1}$ & $\%$ \\
\hline & \multicolumn{12}{|c|}{ Plant Cane } \\
\hline 40 & $6.1 \mathrm{~b}$ & 15.2 & 3.2 & 8.1 & 2.2 & 5.4 & $11.5 b$ & 28.7 & 0.8 & 1.9 & $12.2 \mathrm{~b}$ & 31 \\
\hline 80 & $9.7 \mathrm{a}$ & 12.1 & 5.9 & 7.3 & 3.1 & 3.9 & $18.7 \mathrm{ab}$ & 23.4 & 1.3 & 1.6 & $20.0 \mathrm{ab}$ & 25 \\
\hline 120 & $13.5 \mathrm{a}$ & 11.2 & 6.7 & 5.6 & 3.2 & 2.7 & $23.4 \mathrm{a}$ & 19.5 & 1.5 & 1.3 & 24.9 a & 21 \\
\hline \multirow[t]{2}{*}{ LSD } & 6.9 & NS & NS & NS & NS & NS & 11.4 & NS & NS & NS & 11.6 & NS \\
\hline & \multicolumn{12}{|c|}{ 1st Ratoon } \\
\hline 40 & 1.0 & 2.4 & 0.4 & 1.1 & 0.6 & 1.4 & 2.0 & 4.9 & \multicolumn{2}{|c|}{$\longrightarrow$} & \multicolumn{2}{|c|}{-} \\
\hline 80 & 1.8 & 2.3 & 1.1 & 1.4 & 1.5 & 1.9 & 4.4 & 5.5 & \multicolumn{2}{|c|}{$\longrightarrow$} & \multicolumn{2}{|c|}{-} \\
\hline 120 & 1.8 & 1.5 & 1.2 & 1.0 & 1.5 & 0.4 & 3.5 & 2.9 & \multicolumn{2}{|c|}{ 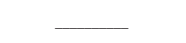 } & \multicolumn{2}{|c|}{ 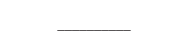 } \\
\hline \multirow[t]{2}{*}{$\underline{\mathrm{LSD}}$} & NS & NS & NS & NS & NS & NS & NS & NS & & & & \\
\hline & \multicolumn{12}{|c|}{$2^{\text {nd }}$ Ratoon } \\
\hline 40 & 0.5 & 1.2 & 0.2 & 0.4 & 0.2 & 0.4 & 0.8 & 2.1 & \multirow{2}{*}{\multicolumn{2}{|c|}{-}} & \multicolumn{2}{|c|}{-} \\
\hline 80 & 0.7 & 0.9 & 0.3 & 0.4 & 0.3 & 0.4 & 1.3 & 1.7 & & & & \\
\hline 120 & 0.7 & 0.6 & 0.4 & 0.4 & 0.5 & 0.4 & 1.6 & 1.3 & \multicolumn{2}{|c|}{$\underline{-}$} & \multicolumn{2}{|c|}{$\longrightarrow$} \\
\hline \multirow[t]{2}{*}{ LSD } & NS & NS & NS & NS & NS & NS & NS & NS & & & & \\
\hline & \multicolumn{12}{|c|}{ 3rd Ratoon } \\
\hline 40 & $0.3 \mathrm{~b}$ & $0.7 \mathrm{~b}$ & $0.04 \mathrm{~b}$ & $0.11 \mathrm{~b}$ & $0.3 \mathrm{~b}$ & $0.7 \mathrm{ab}$ & $0.6 \mathrm{~b}$ & $1.6 \mathrm{~b}$ & \multicolumn{2}{|c|}{$\longrightarrow$} & \multirow{2}{*}{\multicolumn{2}{|c|}{$\overline{ }$}} \\
\hline 80 & $1.0 \mathrm{a}$ & $1.3 \mathrm{a}$ & $0.13 a$ & 0.17 a & $0.8 \mathrm{a}$ & $1.2 \mathrm{a}$ & $2.1 \mathrm{a}$ & $2.6 \mathrm{a}$ & & & & \\
\hline 120 & $0.9 \mathrm{a}$ & $0.8 \mathrm{~b}$ & $0.14 \mathrm{a}$ & $0.12 \mathrm{ab}$ & $0.9 \mathrm{a}$ & $0.6 \mathrm{~b}$ & $1.8 \mathrm{a}$ & $1.5 \mathrm{~b}$ & & & 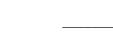 & \\
\hline \multirow[t]{2}{*}{ LSD } & 0.5 & 0.48 & 0.07 & 0.05 & 0.4 & 0.5 & 1.0 & 0.9 & & & & \\
\hline & \multicolumn{12}{|c|}{ Sum of crop seasons } \\
\hline 40 & $7.8 \mathrm{~b}$ & 19.6 & 3.9 & 9.8 & 3.2 & 8.0 & $14.9 \mathrm{~b}$ & 37.3 & 0.8 & 1.9 & $15.7 \mathrm{~b}$ & 39 \\
\hline 80 & $13.2 a b$ & 16.6 & 7.4 & 9.2 & 5.9 & 7.3 & $26.5 \mathrm{ab}$ & 33.1 & 1.3 & 1.6 & $27.8 \mathrm{ab}$ & 35 \\
\hline 120 & 16.9 a & 14.1 & 8.5 & 7.0 & 5.0 & 4.2 & 30.4 a & 25.3 & 1.5 & 1.3 & 31.9 a & 27 \\
\hline LSD & 8.0 & NS & NS & NS & NS & NS & 14 & NS & NS & NS & 14 & NS \\
\hline
\end{tabular}

LSD: least significant difference; NS: not significant. Same letters in a column indicate no differences according to the Tukey test $(p<0.05)$. 
type, as $\mathrm{N}$ fertilization would be far more likely to have a carryover effect on ratoons when sugarcane is grown on soils low in organic matter and with limited capacity for mineralization.

The aerating effect of conventional tillage operations at the SA and SL sites would have created conditions conducive to microorganisms mineralizing $\mathrm{N}$ from soil organic matter, including the breakdown of organic matter linked to soil solid surfaces. Increased mineralisation of organic matter would have enhanced soil supplies of plant-available $\mathrm{N}$, and reduced sugarcane responses to $\mathrm{N}$ fertilization as previously reported by Otto et al. (2013).

Many studies have found sucrose content to be unaffected by $\mathrm{N}$ fertilization (Franco et al., 2010; Thorburn et al., 2011; Yang et al., 2013), while in some cases a nega-

Table 4 - Recovery of ${ }^{15} \mathrm{~N}$-fertilizer ( $\mathrm{kg} \mathrm{ha}^{-1}$ and \%) applied at sugarcane planting, as evaluated in four crop seasons. São Martinho experiment - SM.

\begin{tabular}{|c|c|c|c|c|}
\hline & Stalks & Dry Leaves & Tops & Above ground \\
\hline & \multicolumn{4}{|c|}{$\mathrm{kg} \mathrm{ha}^{-1}$} \\
\hline Plant Cane & $18.9 \mathrm{a}$ & $3.1 \mathrm{a}$ & 2.7 & $24.7 \mathrm{a}$ \\
\hline 1st Ratoon & $1.3 \mathrm{~b}$ & $0.6 \mathrm{~b}$ & 2.0 & $3.9 \mathrm{~b}$ \\
\hline $2^{\text {nd }}$ Ratoon & $0.9 b$ & $0.6 \mathrm{~b}$ & 1.4 & $2.9 \mathrm{~b}$ \\
\hline $3^{\text {rd }}$ Ratoon & $1.3 \mathrm{~b}$ & $0.1 \mathrm{~b}$ & 1.3 & $2.8 b$ \\
\hline Sum of crop seasons & 22.4 & 4.5 & 7.4 & 34.3 \\
\hline LSD & 1.9 & 0.5 & NS & 3.0 \\
\hline Plant Cane & $24 \mathrm{a}$ & $3.9 \mathrm{a}$ & 3.4 & $31 \mathrm{a}$ \\
\hline $1^{\text {st }}$ Ratoon & $1.6 \mathrm{~b}$ & $0.8 \mathrm{~b}$ & 2.5 & $4.9 \mathrm{~b}$ \\
\hline $2^{\text {nd }}$ Ratoon & $1.1 \mathrm{~b}$ & $0.7 \mathrm{bc}$ & 1.8 & $3.6 \mathrm{~b}$ \\
\hline 3rd Ratoon & $1.7 \mathrm{~b}$ & $0.2 \mathrm{c}$ & 1.6 & $3.5 b$ \\
\hline Sum of crop seasons & 28 & 5.6 & 9.3 & 43 \\
\hline LSD & 7 & 0.5 & NS & 3.8 \\
\hline
\end{tabular}

LSD: least significant difference; NS: not significant. Same letters in a column indicate no differences by the Tukey test $(p<0.05)$. tive effect was observed when a high $\mathrm{N}$ amount ( $>200 \mathrm{~kg}$ $\mathrm{ha}^{-1}$ ) was applied at planting (Wiedenfeld, 1995), owing to a decrease in sucrose content. When the accumulated yield in four harvests was averaged over the three sites, there was an increase of $1.93,2.23$ and $1.88 \mathrm{Mg} \mathrm{ha}^{-1}$ in sugar yield for 40,80 and $120 \mathrm{~kg} \mathrm{~N}^{-1}$ as compared to the unfertilized treatment; these gains were statistically different. Considering economic issues and also the potentially negative impact to the environment from excessive $\mathrm{N}$ doses, there is good reason for concern about the evidence in Table 2 documenting low residual availability of $\mathrm{N}$ applied at planting to the following ratoons.

Our results agree with previous findings that fertilizer $\mathrm{N}$ applied at planting is much more available in the first growing season than to subsequent ratoon crops. For example, Takahashi (1969) found in Hawaii that plant cane accounted for $79 \%$ of total fertilizer ${ }^{15} \mathrm{~N}$ uptake, with $15 \%, 2 \%$ and $4 \%$ recoveries by the first, second and third ratoon, respectively. In two experiments with sugarcane grown in either the summer or winter, Takahashi (1970a) found that crop recovery of fertilizer ${ }^{15} \mathrm{~N}$ applied at planting was largely due to plant cane (around $80 \%$ on average for both experiments), the rest being partitioned among three subsequent ratoons. An additional study by Takahashi (1970b) showed the same trend; approximately $92 \%$ of ${ }^{15} \mathrm{~N}$ uptake following fertilization at planting was by the plant cane, with the remainder being divided among the three ratoons. More recently, work in Brazil by Basanta et al. (2003) showed that plant cane accounted for $81 \%$ of crop ${ }^{15} \mathrm{~N}$ uptake from fertilizer applied at planting, as compared to $14 \%$ by the first ratoon and $5 \%$ by the second ratoon. This means that the contribution of fertilizer $\mathrm{N}$ from the previous crop is very limited, and will typically account for less than $5 \%$ of total $\mathrm{N}$ uptake by ratoons. Moreover, our data clearly show that the first ratoon dominates residual uptake of fertilizer $\mathrm{N}$ applied at planting.

Table 5 - Recovery of ${ }^{15} \mathrm{~N}$-fertilizer ( $\mathrm{kg} \mathrm{ha}^{-1}$ and \%) applied at sugarcane planting, as evaluated in two crop seasons. São Luis Experiment - SL.

\begin{tabular}{|c|c|c|c|c|c|c|c|c|c|c|c|c|}
\hline \multirow{2}{*}{$\begin{array}{l}\text { N Rates } \\
\text { g ha }^{-1}\end{array}$} & \multicolumn{2}{|c|}{ Stalks } & \multicolumn{2}{|c|}{ Dry Leaves } & \multicolumn{2}{|c|}{ Tops } & \multicolumn{2}{|c|}{ Above ground } & \multicolumn{2}{|c|}{ Roots } & \multicolumn{2}{|c|}{ Whole Plant } \\
\hline & $\mathrm{kg} \mathrm{ha}^{-1}$ & $\%$ & $\mathrm{~kg} \mathrm{ha}^{-1}$ & $\%$ & $\mathrm{~kg} \mathrm{ha}^{-1}$ & $\%$ & $\mathrm{~kg} \mathrm{ha}^{-1}$ & $\%$ & $\mathrm{~kg} \mathrm{ha}^{-1}$ & $\%$ & $\mathrm{~kg} \mathrm{ha}^{-1}$ & $\%$ \\
\hline & \multicolumn{12}{|c|}{ Plant Cane } \\
\hline 40 & $6.1 \mathrm{~b}$ & $15 a b$ & $2.0 \mathrm{~b}$ & 5 & $2.7 \mathrm{~b}$ & $6.8 \mathrm{ab}$ & $10.8 \mathrm{~b}$ & $27 a b$ & 1.7 & 4 & $12.5 \mathrm{~b}$ & $31 a b$ \\
\hline 80 & $14.5 \mathrm{a}$ & $18 a$ & $3.8 \mathrm{ab}$ & 5 & $7.4 \mathrm{a}$ & $9.3 \mathrm{a}$ & $25.8 \mathrm{a}$ & $32 \mathrm{a}$ & 2.3 & 3 & $28.1 \mathrm{a}$ & $35 a$ \\
\hline 120 & $12.0 \mathrm{a}$ & $10 \mathrm{~b}$ & $5.4 \mathrm{a}$ & 5 & $5.5 \mathrm{ab}$ & $4.6 \mathrm{~b}$ & $22.9 a$ & $19 \mathrm{~b}$ & 4.1 & 3 & $26.9 a$ & $22 b$ \\
\hline \multirow[t]{2}{*}{ LSD } & 5.2 & 7.0 & 2.2 & NS & 3.7 & 4.0 & 6.8 & 8 & NS & NS & 7.6 & 9 \\
\hline & \multicolumn{12}{|c|}{$1^{\text {st }}$ Ratoon } \\
\hline 40 & 0.5 & 1.0 & 0.5 & 1.4 & 0.4 & 0.9 & 1.4 & 3.4 & & & 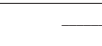 & \\
\hline 80 & 0.8 & 1.1 & 1.3 & 1.6 & 1.6 & 1.9 & 3.7 & 4.6 & & & & \\
\hline 120 & 1.9 & 1.6 & 1.7 & 1.4 & 1.4 & 1.2 & 5.0 & 4.1 & & & 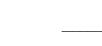 & \\
\hline \multirow[t]{2}{*}{$\underline{\mathrm{LSD}}$} & NS & NS & NS & NS & NS & NS & NS & NS & & & 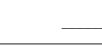 & - \\
\hline & \multicolumn{12}{|c|}{ Sum of crop season } \\
\hline 40 & $6.5 b$ & $16.3 a b$ & $2.5 \mathrm{~b}$ & 6.2 & $3.1 \mathrm{~b}$ & $7.8 \mathrm{ab}$ & $12.1 \mathrm{~b}$ & $30.3 a b$ & 1.7 & 4 & $13.8 \mathrm{~b}$ & $34.6 \mathrm{ab}$ \\
\hline 80 & $15.4 \mathrm{a}$ & $19.2 \mathrm{a}$ & $5.1 \mathrm{ab}$ & 6.4 & $9.0 \mathrm{a}$ & $11.2 \mathrm{a}$ & $29.5 \mathrm{a}$ & 36.8 a & 2.3 & 3 & $31.7 \mathrm{a}$ & 39.7 a \\
\hline 120 & $13.9 \mathrm{a}$ & $11.6 \mathrm{~b}$ & $7.0 \mathrm{a}$ & 5.8 & $6.9 a b$ & $5.8 b$ & $27.8 \mathrm{a}$ & $23.2 b$ & 4.1 & 3 & $31.9 \mathrm{a}$ & $26.6 b$ \\
\hline LSD & 5.2 & 6.8 & 3.7 & NS & 4.7 & 5.1 & 7.5 & 7.7 & NS & NS & 8.9 & 10 \\
\hline
\end{tabular}

LSD: least significant difference; NS: not significant. Same letters in a column indicate no differences by the Tukey test $(p<0.05)$. 
As expected, the efficiency of ${ }^{15} \mathrm{~N}$ recovery was decreased by higher application rates. The main fate of $\mathrm{N}$ fertilizer (about 20 to $40 \%$ ) applied to sugarcane is to remain in the soil, where the $\mathrm{N}$ immobilized by microorganisms resides in the organic fraction and is temporarily unavailable to the crop (Gava et al., 2005; Oliveira et al., 2000). N Fertilizer is also subject to loss through leaching, denitrification or $\mathrm{NH}_{3}$ volatilization, which can occur from senescing plant leaves as well as from soils amended with alkalizing fertilizers. During leaf senescence, a reduction in the activities of the enzymes glutamine synthetase and glutamate synthetase leads to $\mathrm{NH}_{4}{ }^{+}$accumulation in the plant (Mattsson et al., 1998). As high $\mathrm{NH}_{4}{ }^{+}$concentrations are phytotoxic (HoltanHartwing and Bockman, 1994; Mattsson et al., 1998), this accumulation may result in natural losses of $\mathrm{NH}_{3}$ via the transpiration stream. For sugarcane, $\mathrm{NH}_{3}$ losses were estimated indirectly in Mauritius ( $\mathrm{Ng}$ Kee Kwong and Deville, 1994) to be about $100 \mathrm{~kg} \mathrm{~N} \mathrm{ha}^{-1} \mathrm{yr}^{-1}$.

The 60 to $70 \%$ deficit in ${ }^{15} \mathrm{~N}$ recovery observed in our work was probably not associated with $\mathrm{N}$ losses through leaching, which were found to be very minor in previous studies carried out with sugarcane in Brazil. For instance, leaching losses of fertilizer ${ }^{15} \mathrm{~N}$ were only $0.44 \mathrm{~kg}$ $\mathrm{N} \mathrm{ha}^{-1} \mathrm{yr}^{-1}$ in a study by Bologna-Campbell et al. (2013), and were attributed to $\mathrm{N}$ mineralization. In the SA experiment, Ghiberto et al. (2009) evaluated water flow through the soil using tensiometers and soil solution extractors to measure the amount of $\mathrm{N}$ lost by leaching. The results showed losses of $15 \mathrm{~kg} \mathrm{~N}^{-1}$ of $\mathrm{N}$ during the plant cane cycle, but only $21 \mathrm{~g} \mathrm{ha}^{-1}$ of fertilizer-derived N. Outside Brazil, a lysimeter study by Ng Kee Kwong and Deville (1984) showed only small losses of $\mathrm{N}$ by leaching, even in te case of high rainfall events (about $3200 \mathrm{~mm}$ ) during the experimental period. Their findings were attributed to microbial immobilization, which seems the most plausible explanation for our results. Besides reducing plant $\mathrm{N}$ availability, microbial immobilization of fertilizer $\mathrm{N}$ stimulates heterotrophic $\mathrm{C}$ oxidation and thereby promotes long-term depletion of soil organic $\mathrm{C}$ and $\mathrm{N}$ (Khan et al., 2007; Mulvaney et al., 2009).

Denitrification is another process that can lead to fertilizer $\mathrm{N}$ loss, particularly when organic matter has recently been incorporated into fine-textured soils that become waterlogged after heavy rainfall. This type of loss would have been more likely for the SL than the SA or SM experiments, owing to greater rainfall during the first month after $\mathrm{N}$ fertilization (data not presented). In relation to $\mathrm{NH}_{3}$ volatilization, this form of $\mathrm{N}$ loss was probably negligible in our experiments despite the use of urea as the $\mathrm{N}$ source, because the urea was placed at the bottom of the planting furrow and incorporated as it was applied.

\section{Conclusion}

In three ${ }^{15} \mathrm{~N}$-tracer experiments involving four crop seasons, $\mathrm{N}$ applied at planting increased plant- cane yield for two of the three sites with no residual effect on ratoon production, while the other site showed a significant increase in sucrose content in two of the four growing seasons studied. The combined effect was an increase in sugar yield for three of the 11 site-years evaluated. Crop uptake of fertilizer ${ }^{15} \mathrm{~N}$ totaled 30 to 40 $\%$ over the entire study, $75 \%$ of which was due to plant cane with $13 \%$ in the first ratoon, $7 \%$ in the second ratoon and $5 \%$ in the third ratoon. The low residual benefits limit the value of $\mathrm{N}$ fertilization at planting, and enhance the need to avoid excessive $\mathrm{N}$ rates that have negative consequences for economic profitability and the environment.

\section{Acknowledgments}

We are grateful to the Sugarcane Technology Center (CTC), the "Santa Adélia", "São Martinho" and "São Luiz" Sugar Mills for their support and to the São Paulo State Foundation for Research Support (FAPESP) for funding the project.

\section{References}

Barrie, A.; Prosser, S.J. 1996. Automated analysis of light-element stable isotopes by isotope ratio mass spectrometry. p. 1-46. In: Boutton T.W.; Yamasaki S.I., eds. Mass spectrometry of soil. Marcel Dekker, New York, NY, USA.

Basanta, M.V.; Dourado-Neto, D.; Reichart, K.; Bacchi, O.O.S.; Oliveira, J.C.M.; Trivelin, P.C.O.; Timm, L.C.; Tominaga, T.T.; Correchel, V.; Cássaro, F.A.M.; Pires, L.F.; Macedo, J.R. 2003. Management effects on nitrogen recovery in a sugarcane crop grown in Brazil. Geoderma 116: 235-248.

Blackburn, F. 1984. Sugar-Cane. Longman, London, UK.

Bologna-Campbell, I.; Franco, H.C.J.; Vitti, A.C.; Faroni, C.E.; Costa, M.C.G.; Trivelin, P.C.O. 2013. Impact of nitrogen and sulphur fertilisers on yield and quality of sugarcane plant crop. Sugar Tech 15: 424-428.

Fortes, C.; Trivelin, P.C.O.; Vitti, A.C. 2012. Long-term decomposition of sugarcane harvest residues in Sao Paulo state, Brazil. Biomass and Bioenergy 42: 189-198.

Franco, H.C.J.; Otto, R.; Faroni, C.E.; Vitti, A.C.; Oliveira, E.C.A.; Trivelin, P.C.O. 2011. Nitrogen in sugarcane derived from fertilizer under Brazilian field conditions. Field Crops Research 121: 29-41.

Franco, H.C.J.; Trivelin, P.C.O.; Faroni, C.E.; Vitti, A.C.; Otto, R. 2010. Stalk yield and technological attributes of planted cane as related to nitrogen fertilization. Scientia Agricola 67: 579-590.

Gava, G.J.C.; Trivelin, P.C.O.; Vitti, A.C.; Oliveira, M.W. 2005. Urea and sugarcane straw nitrogen balance in a soil-sugarcane crop system. Pesquisa Agropecuária Brasileira 40: 689-695.

Ghiberto, P.J.; Libardi, P.L.; Brito, A.S.; Trivelin, P.C.O. 2009. Leaching of nutrients from a sugarcane crop growing on an Ultisol in Brazil. Agriculture Water Management 96: 14431448

Khan, S.A.; Mulvaney, R.L.; Ellsworth, T.R.; Boast, C.W. 2007. The myth of nitrogen fertilization for soil carbon sequestration. Journal of Environmental Quality 36: 1821-1832. 
Holtan-Hartwing, L.; Bockman, O.C. 1994. Ammonia exchange between crops and air. Norwegian Journal of Agricultural Sciences 14: 5-40.

Mattsson, M.; Husted, S.; Schjoerring, J.K. 1998. Influence of nutrition and metabolism on ammonia volatilization in plants. Nutrient Cycling in Agroecosystems 51: 35-40.

Mulvaney, R.L.; Khan, S.A.; Ellsworth, T.R. 2009. Synthetic nitrogen fertilizers deplete soil nitrogen: a global dilemma for sustainable cereal production. Journal of Environmental Quality 38: 2295-2314.

Ng Kee Kwong, K.F.; Deville, J. 1984. Nitrogen leaching from soils cropped with sugarcane under the humid tropical climate of Mauritius, Indian Ocean. Journal of Environmental Quality 13: 471-474.

Ng Kee Kwong, K.F.; Deville, J. 1994. Application of ${ }^{15} \mathrm{~N}$-labelled urea to sugar cane through a drip-irrigation system in Mauritius. Fertilizer Research 39: 223-228.

Oliveira, J.C.M.; Reichardt, K.; Bacchi, O.O.S.; Timm, L.C.; Dourado-Neto, D.; Trivelin, P.C.O.; Tominaga, T.T.; Navarro, R.C.; Piccolo, M.C.; Cássaro, F.A.M. 2000. Nitrogen dynamics in a soil-sugar cane system. Scientia Agricola 57: 467-472.

Orlando Filho, J.; Rodella, A.A.; Beltrame, J.A.; Lavorenti, N.A. 1999. Rates, sources and forms of nitrogen application in sugarcane. STAB 17: 39-41 (in Portuguese, with abstract in English).

Otto, R.; Mulvaney, R.L.; Khan, S.A.; Trivelin, P.C.O. 2013. Quantifying soil nitrogen mineralization to improve fertilizer nitrogen management of sugarcane. Biology and Fertility of Soils 49: 893-904.

Otto, R.; Trivelin, P.C.O.; Franco, H.C.J.; Faroni, C.E.; Vitti, A.C. 2009. Root system distribution of sugar cane related to nitrogen fertilization, evaluated by two methods: monolith and probes. Revista Brasileira de Ciência do Solo 33: 601-611.

Spironello, A.; Raij, B. van; Penatti, C.P.; Cantarella, H.; Morelli, J.L.; Orlando Filho, J.; Landell, M.G.A.; Rosseto, R. 1997. Other industrial crops. p. 233-239. In: Raij, B. van; Cantarella, H.; Quaggio, J.A.; Furlani, A.M.C., eds. Fertilization and liming recommendation for São Paulo state. Instituto Agronômico, Campinas, SP, Brazil (in Portuguese).
Takahashi, D.T. 1969. Fate of applied fertilizer nitrogen as determined by the use of ${ }^{15} \mathrm{~N}$. II. Summer plant and ratoon crops at Hilo, Hawaii. Hawaiian Planter's Record 58: 13-20.

Takahashi, D.T. 1970a. Fate of applied fertilizer nitrogen as determined by the use of ${ }^{15} \mathrm{~N}$. III. Summer and winter plant and ratoon crops at two locations on Kauai. Hawaiian Planter's Record 58: 53-69.

Takahashi, D.T. 1970b. Fate of unrecovered fertilizer nitrogen in lysimeter studies with ${ }^{15} \mathrm{~N}$. Hawaiian Planter's Record 58: 95101.

Thorburn, P.J.; Biggs, J.S.; Webster, A.J.; Biggs, I.M. 2011. An improved way to determine nitrogen fertiliser requirements of sugarcane crops to meet global environmental challenges. Plant and Soil 339: 51-67.

Trivelin, P.C.O.; Lara Cabezas, W.A.R.; Victoria, R.L.; Reichardt, K. 1994. Evaluation of a ${ }^{15} \mathrm{~N}$ plot design for estimating plant recovery of fertilizer nitrogen applied to sugar cane. Scientia Agricola 51: 226-234.

Vieira, M.X.; Trivelin, P.C.O.; Franco, H.C.J.; Otto, R.; Faroni, C.E. 2010. Ammonium chloride as nitrogen source in sugarcane harvested without burning. Revista Brasileira de Ciência do Solo 34: 1165-1174.

Vitti, A.C.; Trivelin, P.C.O.; Gava, G.J.C.; Penatti, C.; Bologna, I.R.; Faroni, C.E.; Franco, H.C.J. 2007. Sugar cane yield related to the residual nitrogen from fertilization and the root system. Pesquisa Agropecuária Brasileira 42: 249-256 (in Portuguese, with abstract in English).

Wiedenfeld, R.P. 1995. Effects of irrigation and $\mathrm{N}$ fertilizer application on sugarcane yield and quality. Field Crops Research 43: 101-108.

Yang, W.; Lia, Z.; Wang, J.; Wu, P.; Zhang, Y. 2013. Crop yield, nitrogen acquisition and sugarcane quality as affected by interspecific competition and nitrogen application. Field Crops Research 146: 44-50. 